\title{
PENGARUH TINGKAT KETINGGIAN AIR MEDIA PEMELIHARAAN TERHADAP KELANGSUNGAN HIDUP DAN PERTUMBUHAN BENIH IKAN GABUS (Channa striata)
}

\section{EFFECT OF VARYING WATER LEVEL ON SURVIVAL RATE AND THE GROWTH OF SNAKEHEAD FISH (Channa striata) SEED}

\author{
Muhammad Nursihan $^{1)}$, Ayu Adhita Damayanti ${ }^{2 *}$, Dewi Putri Lestari ${ }^{1)}$ \\ ${ }^{1)}$ Program Studi Budidaya Perairan Universitas Mataram \\ ${ }^{2)}$ Program Studi Ilmu Kelautan Universitas Mataram \\ *)alamat korespondensi : emailnyasihan@gmail.com
}

\begin{abstract}
Abstrak
Penelitian ini bertujuan untuk mengetahui pengaruh ketinggian air media pemeliharaan terhadap kelangsungan hidup dan pertumbuhan benih ikan gabus (Channa striata). Penelitian ini menggunakan Rancangan Acak Lengkap dengan lima perlakuan, yakniP1 (Ketinggian air 3 $\mathrm{cm}$ ), P2 (Ketinggian air $5 \mathrm{~cm}$ ), P3 (Ketinggian air $7 \mathrm{~cm}$ ), P4 (Ketinggian air $9 \mathrm{~cm}$ ), P5 (Ketinggian air $11 \mathrm{~cm}$ ) dan setiap perlakuan memiliki 3 ulangan sehingga total percobaan sebanyak 15 unit. Hasil penelitian menunjukkan bahwa terdapat pengaruh yang nyata $(\mathrm{p}<0,05)$ terhadap kelangsungan hidup, pertumbuhan mutlak dan pertumbuhan spesifik, sehingga dilakukan uji lanjut untuk mengetahui perlakuan terbaik dalam menghasilkan kelangsungan hidup, pertumbuhan mutlak dan pertumbuhan spesifik benih ikan gabus, diketahui bahwa P1 (Ketinggian air $3 \mathrm{~cm}$ ) merupakan perlakuan dengan kelangsungan hidup terbaik sebesar 91,7\% bagi benih ikan gabus. Sedangkan P2 (Ketinggian $5 \mathrm{~cm}$ ) merupakan perlakuan terbaik dalam menghasilkan pertumbuhan mutlak dan spesifik.
\end{abstract}

Kata kunci: ketinggian air, ikan gabus, kelangsungan hidup, pertumbuhan mutlak, pertumbuhan spesifik.

\begin{abstract}
This research aimed to know the effect of varying water level on survival rate and the growth of snakehead fish (Channa striata) seed. This study used a Completely Randomized Design with five treatments, namely P1 (water level $3 \mathrm{~cm}$ ), P2 (water level $5 \mathrm{~cm}$ ), P3 (water level $7 \mathrm{~cm}$ ), P4 (water level $9 \mathrm{~cm}$ ), P5 (water level $11 \mathrm{~cm}$ ) and each treatment has 3 replications so that the total experiment is 15 units. The results showed that there was a significant influence $(\mathrm{p}<0.05)$ on survival rate, absolute growth and specific growth, so that further tests were carried out to find out the best treatment on survival rate, absolute growth and specific growth of snake head seed, it was known that P1 ( $3 \mathrm{~cm}$ water level) is the best survival rate treatment of $91.7 \%$ for snakehead seeds. Whereas $\mathrm{P} 2$ (height $5 \mathrm{~cm}$ ) is the best treatment in producing absolute and specific growth.
\end{abstract}

Keywords: water level, snakehead fish, survival rate, absolute growth, specific growth 


\section{PENDAHULUAN}

Ikan gabus (Channa striata) merupakan salah satu komoditas penting yang memiliki nilai ekonomis tinggi di Indonesia. Ikan gabus ini tergolong ke dalam ikan buas yang hidup di berbagai perairan seperti sungai, rawa-rawa, waduk dan danau. Penampilan luar dari ikan gabus memang terbilang jelek dan memiliki bau yang sangat amis. Namun, ikan gabus banyak dimanfaatkan dalam pengobatan karena ikan ini penghasil albumin yang baik bagi kesehatan. Daging Ikan gabus memiliki kandungan albumin yang berpotensi menggantikan serum albumin yang harganya mencapai $\mathrm{Rp} 1,3$ juta per milliliter (Suprayitno, 2003).

Pemanfaatan ikan gabus yang sangat penting, menyebabkan kebutuhan ikan gabus tersebut semakin meningkat. Produksi ikan gabus masih banyak dilakukan dengan cara mengandalkan hasil tangkapan dari alam sehingga intensitas penangkapan ikan gabus di alam menjadi meningkat dan menyebabkan populasinya menurun. Semakin intensifnya penangkapan ikan gabus memberikan dampak terhadap menurunnya populasi ikan gabus di alam (Muslim, 2007).

Upaya yang dapat dilakukan dalam mencegah menurunnya populasi ikan gabus di alam yaitu dengan cara melakukan domestikasi. Salah satu upaya dalam melakukan domestikasi adalah mempertahankan agar ikan dapat bertahan hidup dalam lingkungan akuakulture (wadah terbatas, lingkungan artificial, dan terkontrol (Effendi, 2004),

Selama ini ikan gabus dewasa masih dipelihara dalam lingkungan budidaya seperti kolam terpal dan kolam beton. Kelangsungan hidup ikan gabus dewasa yang dipelihara pada media tersebut termasuk tinggi yaitu berkisar 60-90\%, ini artinya ikan gabus cukup mampu mempertahankan hidupnya dalam kondisi lingkungan yang berbeda. Namun, pada pemeliharaan larva ikan gabus dengan media akuarium, tingkat kelangsungan hidupnya berkisar $10-40 \%$. Nilai kelangsungan hidup ini termasuk rendahbila dibandingkan dengan larva ikan lainnya yang sudah terbiasa dalam lingkungan budidaya. Hal ini sesuai dengan pernyataan Muslim (2013), bahwa kondisi larva belum terbiasa dengan lingkungan terkontrol seperti akuarium. Larva yang digunakan berasal dari perairan umum yang bebas berkeliaran di alam, sehingga begitu dikondisikan dalam lingkungan terbatas maka fisiologi larva jadi tertekan, sehingga dapat menyebabkan kematian. Permasalahan ini dapat diatasi dengan memanipulasi lingkungan pada media akuarium salah satunya adalah dengan mengatur tingkat ketinggian airnya.

Ikan gabus diketahui bergerak ke permukaan untuk mengambil oksigen langsung dari udara dengan alat bantu pernapasan tambahan pada bagian atas insangnya. Oleh karena itu, diduga ketinggian air mempengaruhi penggunaan energi dalam aktivitasnya. Penelitian sebelumnya yang dilakukan oleh Extrada (2013) menggunakan pakan cacing sutra yang bersifat tenggelam memiliki hasil pertumbuhan yang tidak signifikan. Pemberian jenis pakan yang berbeda pada ikan gabus, diduga akan mempengaruhi aktivitas ikan gabus. Ikan gabus akan lebih lama berada di dasar perairan apabila diberi pakan yang sifatnya tenggelam dibandingkan pakan yang sifatnya terapung sehingga akan berdampak pada energi yang di keluarkan.

Saat ini pembudidaya ikan gabus mulai memberikan pakan terapung yang menyebabkan ikan gabus akan mengeluarkan energi lebih banyak selain untuk bernafas, juga untuk mencari makan karena bertambahnya waktu di permukaan. Banyaknya jumlah energi yang dikeluarkan oleh benih ikan gabus dikhawatirkan akan berdampak pada pertumbuhan dan tingkat kelangsungan hidupnya.

Pemeliharaan benih ikan gabus dengan ketinggian tertentu masih terbatas informasinya. Penelitian pada ikan lainnya sebelumnya menggunakan metode ketinggian air telah dilakukan pada ikan lele. Witjaksono (2009), menyatakan bahwa ketinggian air yang tinggi menyebabkan 
jarak ke permukaan semakin besar sehingga mempengaruhi aktivitas ikan lele dalam mengambil oksigen langsung ke udara. Semakin besar jarak yang ditempuh untuk mengambil oksigen ke permukaan maka semakin besar pula energi yang terpakai sehingga akan berpengaruh terhadap pertumbuhan ikan lele. Oleh sebab itu, perlu dilakukan penelitian pada ikan gabus untuk mengetahui pengaruh ketinggian air pada media pemeliharaan terhadap kelangsungan hidup dan pertumbuhan benih ikan gabus (Channa striata).

\section{METODE PENELITIAN Waktu dan Tempat}

Penelitian ini dilaksanakan pada tanggal 2 November -2 Desember 2019, bertempat di Instalasi Pribadi, Jalan Untung Surapati no. 26, Kampung Jawa Praya, Kecamatan Praya, Kabupaten Lombok Tengah.

\section{Alat dan Bahan}

Alat yang digunakan pada penelitian ini adalah akuarium 15 buah, timbangan digital, penggaris, alat sipon, DO Kit, TAN Kit, plastik hitam, Aerator, Termometer, $\mathrm{pH}$ meter, alat tulis dan kamera. Sedangkan bahan yang digunakan pada penelitian ini yaitu benih ikan gabus dan pakan komersil.

\section{Metode Penelitian}

Penelitian ini menggunakan Rancangan Acak Lengkap (RAL) dengan 5 perlakuan dan masing-masing perlakuan memiliki 3 kali ulangan. Taraf perlakuan penelitian ini adalah :P1 : Ketinggian air 3 $\mathrm{cm}, \mathrm{P} 2$ : Ketinggian air $5 \mathrm{~cm}, \mathrm{P} 3$ : Ketinggian air $7 \mathrm{~cm}, \mathrm{P} 4$ : Ketinggian air $9 \mathrm{~cm}, \mathrm{P5}$ : Ketinggian air $11 \mathrm{~cm}$

\section{Parameter Penelitian}

Parameter yang diamati dalam penelitan ini adalah kelangsungan hidup = (Nt/No)x 100\%; laju pertumbuhan berat dan panjang mutlak $=(W t-W o),(L t-L o)$; laju pertumbuhan berat dan panjang spesifik $=(\ln$ wt - ln wo)/tx $100 \%$, (ln lt - ln lo)/tx100\%. $\mathrm{Nt}=$ jumlah ikan akhir, $\mathrm{N} 0=$ jumlah ikan awal, $\mathrm{Wt}=$ berat akhir, $\mathrm{Wo}=$ berat awal, $\mathrm{Lt}=$ panjang akhir, Lo = panjang awal. Berpengaruh tidaknya perlakuan ditentukan dengan analisis sidik ragam Anova, Apabila terdapat perbedaan antara perlakuan maka dilanjutkan dengan uji lanjut BNT, BNJ, dan Duncan, untuk menentukkan penggunaan uji lanjut dilihat berdasarkan nilai koefisien keseragaman.

\section{HASIL DAN PEMBAHASAN}

Berdasarkan penelitian yang telah dilakukan diperoleh data yaitu kelangsungan hidup (SR), pertumbuhan mutlak dan pertumbuhan spesifik

\section{Kelangsungan Hidup (SR)}

Dari hasil pengamatan selama 30 hari terhadap jumlah tingkat kelangsungan hidup (SR) benih ikan gabus, dapat dilihat pada Gambar 1.

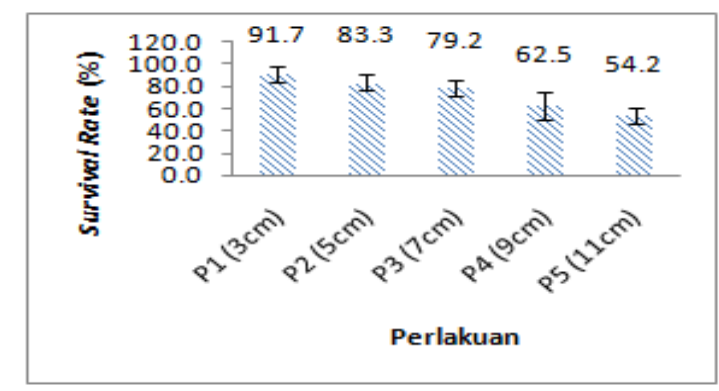

Gambar 1. Kelangsungan Hidup Benih Ikan Gabus

Berdasarkan Gambar 1. diperoleh angka kelangsungan hidup benihikan gabus yakni berkisar antara 54,2 - 91,7\%, angka kelangsungan hidup benihikan gabus tertinggi terdapat pada perlakuanP1 dengan nilai kelangsungan hidup sebesar 91,7\% kemudian P2 dengan nilai kelangsungan hidup sebesar $83,3 \%$ selanjutnya diikuti P3 dengan nilai $79,2 \%$ sedangkan untuk angka kelangsungan hidup terendah terdapat pada 2 perlakuan lainnya yaitu P4 dan P5 dengan nilai kelangsungan hidupmasing-masing sebesar $62,5 \%$ dan 54,2\%. Hasil analisis Kruskal Wallis menunjukkan bahwa terdapat perbedaan yang nyata pada setiap perlakuan untuk kelangsungan hidup benih ikan gabus. 
Angka kelangsungan hidup pada penelitian ini tergolong baik. Hal ini sesuai dengan pernyataan Husen, (1985) dalam Simangunsong, (2017) dalam Afdola, (2018) yang mengatakan bahwa tingkat kelangsungan hidup $\geq 50 \%$ tergolong baik, $30-50 \%$ sedang dan untuk kelangsungan hidup kurang dari 30\% dikatakan tidak baik, dan dari angka kelangsungan hidup benihikan gabus dalam penelitian ini yang berkisar antara $54,2 \%-91,7 \%$ adalah tergolong baik.

Pada penelitian ini, semakin luas wadah dan ketinggian air rendah, maka akan menyebabkan kepadatannya tinggi dan sebaliknya semakin sempit wadah dan ketinggian airnya tinggi, maka kepadatannya rendah. Hal ini dapat disimpulkan berdasarkan adanya perbedaan pengaruh luas ruang gerak dan persaingan pakan dalam wadah budidaya antara setiap perlakuan. Dalam hal ini setiap individu benih ikan gabus yang ditebar mendapatkan ruang gerak yang berbeda, sehingga menghasilkan kelangsungan hidup yang berbeda. Tingkat kelangsungan hidup benih ikan gabus yang berbeda pada akhir masa pemeliharaan diduga disebabkan oleh kemampuan adaptasi terhadap lingkungan (perlakuan yang diberikan) yang memiliki luas dan ketinggian yang berbeda. Pada dasarnya tingkat kelangsungan hidup yang dicapai suatu populasi merupakan gambaran hasil interaksi dari kemampuan lingkungan dengan respon populasi terhadap ketersediaan lingkungan tersebut (Lanne-Petter, 1964 dalam Sumantri, 1987)

\section{Laju Pertumbuhan Mutlak}

Data pertumbuhan berat dan panjang mutlak benih ikan gabus selama penelitian disajikan dalam bentuk grafik. Data yang dimasukkan merupakan data selisih panjang dan berat rata-rata benih ikan gabus pada hari ke-0 dengan data rata-rata panjang dan berat benih ikan gabus pada hari ke-30. Data pertumbuhan mutlak dapat dilihat pada Gambar 2. dan Gambar 3.

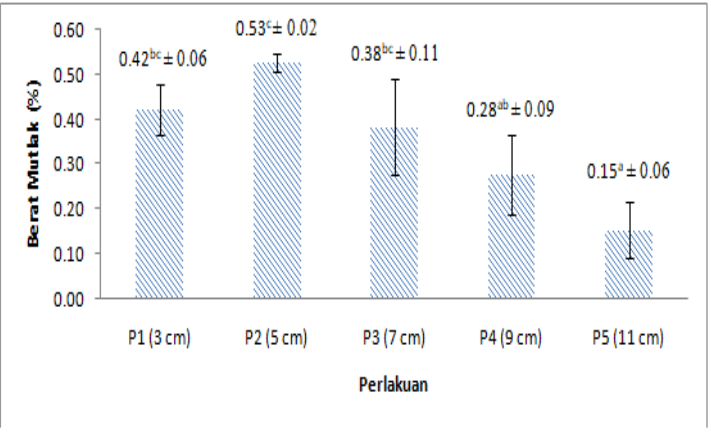

Gambar 2. Pertumbuhan Berat Mutlak Benih Ikan Gabus

Dari Gambar 2. dapat dilihat bahwa pertumbuhan berat mutlak benih ikan gabus pada P2 merupakan perlakuan dengan nilai pertumbuhan tertinggi yakni sebesar 0.53 gram yang kemudian diikuti oleh P1 sebesar 0.42 gram, P3 sebesar 0.28 gram, P4 sebesar 0.28 gram, dan berat mutlak terendah terdapat pada perlakuan P5 sebesar 0.15 gram.

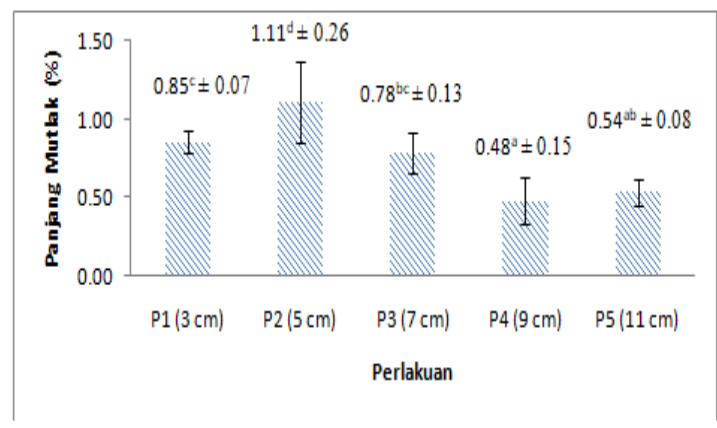

Gambar 3. Pertumbuhan Panjang Mutlak Benih Ikan Gabus

Dari Gambar 3. dapat dilihat bahwa pertumbuhan panjang mutlak benih ikan gabus pada $\mathrm{P} 2$ merupakan perlakuan dengan nilai pertumbuhan tertinggi yakni sebesar $1,11 \mathrm{~cm}$ yang kemudian diikuti oleh P1 sebesar $0.85 \mathrm{~cm}, \mathrm{P} 3$ sebesar $0.75 \mathrm{~cm}, \mathrm{P} 5$ sebesar $0.54 \mathrm{~cm}$, dan panjang mutlak terendah terdapat pada perlakuan P5 sebesar $0.48 \mathrm{~cm}$.

Hasil analisis sidik ragam (ANOVA) menunjukan bahwa tingkat ketinggian air berpengaruh nyata $(\mathrm{p}<0,05)$ terhadap pertumbuhan berat mutlak benih ikan gabus, 
sehingga dilakukan uji lanjut Duncan untuk mengetahui perlakuan terbaik. Hasil uji lanjut Duncan menunjukan bahwa perlakuan P1 berbeda nyata dengan P5, sedangkan P5 berbeda nyata dengan $\mathrm{P} 1, \mathrm{P} 2$, dan P3. Hasil analisis sidik ragam (ANOVA) pada pertumbuhan panjang mutlak yakni terdapat pengaruh yang nyata $(\mathrm{p}<0,05)$ sehingga dilakukan uji lanjut Duncan dan didapatkan hasil bahwa perlakuan P1 tidak berbeda nyata dengan P3, namun berbeda nyata dengan P2, P4 dan P5.

Berdasarkan Gambar 2. dapat dilihat bahwa pertumbuhan berat mutlak pada P2 merupakan perlakuan dengan nilai angka pertumbuhan berat mutlak tertinggi, sedangkan pada P5 merupakan perlakuan dengan nilai angka pertumbuhan yang terendah. Pada perlakuan P1 dengan ketinggian air $3 \mathrm{~cm}, \mathrm{P} 2$ ketinggiannya $5 \mathrm{~cm}$ dan P3 ketinggiannya $7 \mathrm{~cm}$ memiliki ruang gerak yang cukup dan ketinggian airnya sesuai sehingga energi yang dikeluarkan tidak terlalu banyak untuk mengambil oksigen maupun makanan di permukaan. Hal ini sesuai dengan pernyataan Karim (2005) dalam Rizka (2013) bahwa pertumbuhan dapat terjadi jika energi yang di simpan lebih besar dibandingkan energi yang digunakan untuk aktivitas tubuh.

Berdasarkan Gambar 3. dapat dilihat bahwa pertumbuhan panjang mutlak pada $\mathrm{P} 2$ merupakan perlakuan dengan nilai angka pertumbuhan panjang mutlak tertinggi dan merupakan hasil yang terbaik dengan nilai $1,11 \mathrm{~cm}$, sedangkan untuk nilai angka terendah terdapat pada $\mathrm{P} 4$ dengan nilai 0,48 $\mathrm{cm}$. Terlihat pola pertumbuhan panjang dan berat mutlak perlakuan P4 dan P5 lebih rendah dibandingkan dengan perlakuan P3, P2 dan P1 hal ini diduga karena pada pada penelitian ini perlakuan P4 dan P5 memiliki ruang yang terbatas untuk berenang. Benih ikan gabus lebih cenderung berada pada dasar perairan sehingga ketika wadah pemeliharaan memiliki luasan yang terbatas, maka benih ikan gabus akan bersaing untuk memperebutkan ruang gerak. Hal ini didukung dengan penyataan Hoar et al. (1979) yang menyatakanbahwa hubungan timbal-balik antara setiap individu ikan dengan ikan lainnya dipengaruhi oleh jumlah, ruang, ukuran dan spesies. Hubungan ini berpengaruh terhadap pertumbuhan ikan dan besarnya interaksi yang terjadi

\section{Laju Pertumbuhan Spesifik}

Data pertumbuhan panjang dan berat spesifik benih ikan gabus selama penelitian disajikan dalam bentuk grafik. Data yang dimasukkan merupakan hasil perhitungan dari rata-rata berat akhir dikurangi dengan rata-rata berat awal dibagi lama pemeliharaan dan dikalikan 100\%. Data pertumbuhan Berat dan Panjang spesifik benih ikan gabus dapat dilihat pada Gambar 4. dan Gambar 5.

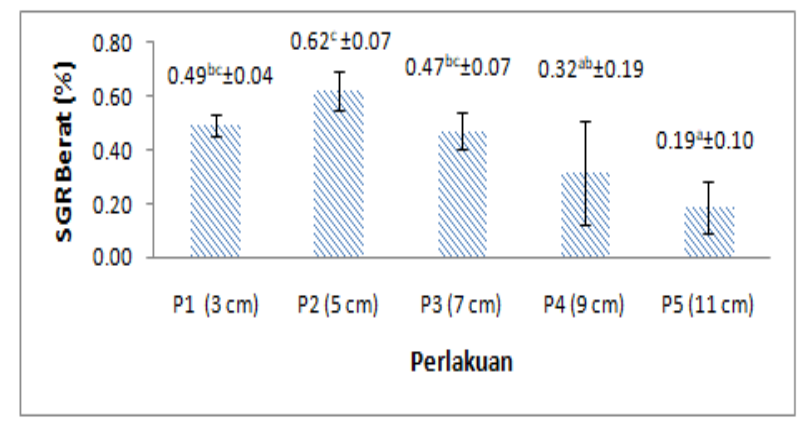

Gambar 4. Pertumbuhan Berat Spesifik Benih Ikan Gabus

Berdasarkan Gambar 4. memperlihatkan pertumbuhan berat spesifik benih ikan gabus pada setiap perlakuan. Nilai pertumbuhan berat spesifik tertinggi ada pada P1 yakni sebesar 0,49\%, kemudian diikuti oleh P2 sebesar 0,62 \%, P3 sebesar $0,47 \%, \mathrm{P} 4$ sebesar $0,32 \%$ dan yang terendah yaitu pada P5 sebesar 0,19\%. 


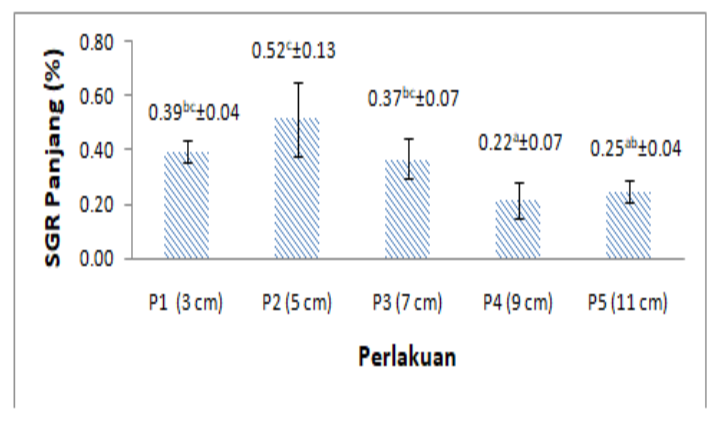

Gambar 5. Pertumbuhan Panjang Spesifik Benih Ikan Gabus

Gambar 5. memperlihatkan pertumbuhan panjang spesifik benih ikan gabus pada setiap perlakuan. Nilai pertumbuhan panjang spesifik pada P1 sebesar $0,39 \%, \mathrm{P} 2$ sebesar $0,52 \%, \mathrm{P} 3$ sebesar $0,37 \%, \mathrm{P} 4$ sebesar $0,22 \%$ dan P5 sebesar $0,25 \%$.

Hasil analisis sidik ragam (ANOVA) menunjukan bahwa tingkat ketinggian air berpengaruh nyata $(\mathrm{p}<0,05)$ terhadap pertumbuhan berat spesifik benih ikan gabus, sehingga dilakukan uji lanjut Duncan untuk mengetahui perlakuan terbaik. Hasil uji lanjut Duncan menunjukan bahwa perlakuan P1 berbeda nyata dengan P4 dan P5, sedangkan $\mathrm{P} 5$ berbeda nyata dengan $\mathrm{P} 1, \mathrm{P} 2$, dan P3. Hasil analisis sidik ragam (ANOVA) pada pertumbuhan panjang spesifik yakni terdapat pengaruh yang nyata $(\mathrm{p}<0,05)$ sehingga dilakukan uji lanjut Duncan dan didapatkan hasil bahwa perlakuan P1 berbeda nyata dengan P4 dan P5 ,P5 berbeda nyata dengan P2.

Pada penelitian ini, ketinggian air berpengaruh terhadap berat spesifik dan panjang spesifik benih ikan gabus. Hal ini berkaitan dengan pola pertumbuhan yang terjadi pada ikan. Pada penelitian ini berat spesifik mengalami pertumbuhan begitupun panjang spesifik. Pola pertumbuhan ini disebut dengan pola isometrik dimana ikan cenderung memiliki pola pertumbuhan yang sama antara berat dan panjangnya. Hal ini sesuai dengan pernyataan Effendi (1997) bahwa Pola pertumbuhan pada ikan terdapat dua macam yaitu pertumbuhan isometrik $(\mathrm{n}=3)$, apabila pertambahan panjang dan berat ikan seimbang.

Berdasarkan Gambar 4. dan 5. memiliki pola grafik yang hampir sama yaitu dengan perlakuan P2 memiliki nilai angka pertumbuhan tertinggi sedangkan P4 dan P5 memiliki nilai angka pertumbuhan terendah. Ketinggian air dalam wadah pemeliharaan akan mempengaruhi ruang gerak bagi benih ikan gabus. Hal ini akan menimbulkan adanya persaingan dalam memperebutkan ruang gerak dan pakan. Pada penelitian ini, laju pertumbuhan harian benih ikan gabus selama pemeliharaan menurun seiring dengan bertambahnya waktu pemeliharaan. Hal ini diduga disebabkan oleh bertambahnya ukuran dan umur benih ikan gabus. Semakin bertambahnya umur dan ukuran benih ikan gabus akan meningkatkan jumlah energi yang dibutuhkan untuk metabolisme dasar, pergerakan, produksi organ seksual, dan mempertahankan tubuhnya, sehingga energi yang digunakan untuk pertumbuhan menjadi berkurang. Hal ini sesuai dengan pernyataan Kleiber (1961) dalamBrett (1979) bahwa laju metabolisme menurun dengan meningkatnya ukuran organisme.

Pada penelitian ini, P1 dan P2 memiliki luasan wadah yang sesuai bagi benih ikan gabus. Luasan wadah tersebut masih dalam tergolong baik bagi benih ikan gabus sehingga menyebabkan ruang gerak bagi benih ikan gabus semakin besar. Pada penelitian ini, kondisi ruang gerak yang luas atau tidak berdesakan, aktivitas setiap individu benih ikan gabus tidak terganggu oleh benih ikan gabus lainnya, sehingga benih ikan gabus akan mendapatkan ruang dan pakan yang cukup sehingga pakan dapat dimanfaatkan dengan baik. Brown (1957) mengatakan bahwa beberapa ikan yang dipelihara dalam wadah yang sama, jika total ruang yang tersedia relatif kecil, maka ikan akan mengganggu satu sama lainnya saat makan dan selama aktivitas normalnya.

Ketinggian air juga sangat berhubungan dengan jenis pakan yang diberikan yaitu pakan bersifat terapung sehingga pakan akan berada di permukaan. 
Hal ini menyebabkan benih ikan gabus akan bergerak menuju permukaan untuk mengambil makanan. Semakin tinggi permukaan air maka akan semakin banyak pula energi yang dihabiskan oleh benih, sehingga energi yang ada dalam tubuh akan banyak dipergunakan untuk bergerak, hal ini yang menyebabkan pertumbuhan benih menjadi lambat. Sebaliknya permukaan air yang lebih rendah akan menghemat pergerakan benih dalam mendapatkan pakan sehingga energi yang ada dapat digunakan semaksimal mungkin untuk pertumbuhan. Hal ini sesuai dengan penelitian Witjaksono (2009) yang menyatakan bahwa ketinggian air yang tinggi menyebabkan jarak ke permukaan semakin besar sehingga mempengaruhi aktivitas ikan lele dalam mengambil oksigen dari udara. Semakin besar jarak yang ditempuh untuk mengambil oksigen ke permukaan maka semakin besar pula energi yang terpakai sehingga akan berpengaruh terhadap pertumbuhan dan kelangsungan hidup ikan lele. Pada penelitian ini, semakin rendah ketinggian air, semakin agresif benih ikan gabus dalam melakukan aktivitasnya. Energi yang dikeluarkan untuk mengambil oksigen dan makanan di permukaaan lebih sedikit sehingga energi yang tersimpan digunakan untuk pertumbuhan benih ikan gabus. Hal ini sesuai dengan pernyataan Schaperclaus dalamHuet (1971) mengemukakan bahwa pertumbuhan hanya terjadi jika energi makanan yang dimakan ikan lebih banyak daripada energi yang diperlukan untuk mempertahankan berat tubuhnya.

\section{KESIMPULAN}

Ketinggian air berpengaruh nyata terhadap kelangsungan hidup, pertumbuhan mutlak dan pertumbuhan spesifik bagi benih ikan gabus. P1 (ketinggian air $3 \mathrm{~cm}$ ) merupakan perlakuan terbaik dalam memberikan kelangsungan hidup bagi benih ikan gabus yakni sebesar $91,7 \%$, sedangkan P2 (ketinggian air $5 \mathrm{~cm}$ ) merupakan perlakuan terbaik dalam memberikan pertumbuhan berat dan panjang spesifik bagi benih ikan gabus.

\section{DAFTAR PUSTAKA}

Afdola, Indra S, Adelina. 2018. Pengaruh Penambahan Probiotik dalam Pakan terhadap Pertumbuhan Benih Ikan Bawal Air Tawar (Colossoma macropomum). Jurnal. 1-11. https://docplayer.info/79297418Jurnal-pengaruh-penambahanprobiotik-dalam-pakan-terhadappertumbuhan-benih-ikan-bawal-airtawar-colossoma-macropomum-olehafdola-nim.html

Brett, J. R. 1979. Environmental factor and growth. Dalam W.R. Holar, D.J. Randal dan J.R Brett (eds). Fish Physiology. Academic Press Inc, London.

Brown, M.E. 1957. The Physiology of Fish. Volume I : Metabolism. Academic Press Inc., New York. P. 361-397.

Huet, M. 1971. Textbook of Fish Culture. Breeding and Cultivation of Fish. Fishing News Books. Ltd. London.

Extrada, E, Ferdinand HT, Yulisman. 2013. Kelangsungan Hidup Dan Pertumbuhan Benih ikan gabus (Channa striata) Pada Berbagai Tingkat Ketinggian Air Media Pemeliharaan. Jurnal. Akuakultur Rawa Indonesia, 1(1) 103-114 (2013). Program Studi Budidaya Perairan Fakultas Pertanian Universitas Sriwijaya, indralaya,ogan ilir 30662.

Hoar, W.S., D.J. Randall, J.R. Brett. 1979. Fish Physiology. Vol III. Bioenergenetics and Growth. Academic Press. New York, San Fransisco, London. P. 559-667.

Muslim. 2007. Potensi, peluang, dan tantangan budidaya ikan gabus (Channa striata) di Sumatera Selatan. Prosiding SeminarNasional Forum Perairan UmumIndonesia IV. Palembang 30 November 2007. Balai Riset Kelautan dan Perairan. Departemen Kelautan dan Perikanan.

Rizka, D. Rayes. 2013. Pengaruh Perubahan Salinitas Terhadap Pertumbuhan dan Sintasan Ikan Kakap Putih (Lates 
Jurnal Perikanan (2020) Volume 10. No. 1 : 84-91

DOI : https://doi.org/10.29303/jp.v10i1.181

calcarifer bloch). Jurnal Kelautan. 6 (1).: 50-51.

Sumantri, W.I. 1987. Pengaruh Kepadatan Terhadap Kelangsungan Hidup Zoea Udang Windu (Penaeus monodon Fab.) Yang Diberi Makanan Alami Isochrysis galbana Parke. Karya Ilmiah. Fakultas Perikanan, Institut Pertanian Bogor. Bogor.

Suprayitno, E. 2003. Penyembuhan Luka dengan Ikan Gabus. Fakultas
Perikanan Universitas Brawijaya. Malang

Witjaksono, A. 2009. Kinerja produksi pendederan lele sangkuriang (clarias sp.) melalui penerapan teknologi ketinggian media air $15 \mathrm{~cm}, 20 \mathrm{~cm}, 25$ $\mathrm{cm}$, dan $30 \mathrm{~cm}$. Skripsi. Fakultas Perikanan dan Ilmu Kelautan. Institut Pertanian Bogor. Bogor. 